\title{
From Symbol to (Some) Substance: Costa Rica's Carbon Neutral Pledge
}

\author{
Julia A. Flagg' \\ Department of Sociology and Environmental Studies Program, \\ Connecticut College \\ Connecticut, United States
}

\section{Abstract}

In 2007, Costa Rican politicians announced that the country would be carbon neutral by 2021. This paper investigates whether this pledge has moved beyond a symbolic commitment and, if so, how. Data consist of interviews conducted with officials in Costa Rica's industry, government, science, and civil society as well as archival research. The findings show that carbon emissions declined after the pledge, but the effects of the great recession mean these declines cannot be directly attributed to the pledge. However, since 2007, there have also been numerous political changes that may contribute to future emissions reductions. Future research on symbolic politics would benefit from investigating how political acts can change from symbolic to more substantive over time as social groups grapple with how to act to fulfill the stated aims. This case study provides an important historical analog for understanding the aftermath of other nations' pledges made at the 2015 global climate meeting.

Keywords: carbon neutral, case study, climate change, Costa Rica, symbolic politics

\section{Introduction}

In recent years, the response to climate mitigation has taken on a more polycentric form (Ostrom, 2010), as groups at diverse levels of scale have adopted strategies to curtail greenhouse gas emissions (Ehrhardt-Martinez et al., 2015). As part of this trend, several nations have made pledges to become carbon neutral in the future (Flagg, 2015). These nations aim to reduce emissions and balance remaining emissions with carbon sequestration or offsets (Fukuda and Tamura, 2010). Given the ambition of carbon neutrality pledges, these commitments represent an encouraging move, a potentially bright spot in climate mitigation efforts, but it is their ambition that also opens them to criticism. If mitigation pledges are not

1 Corresponding author: julia.flagg@conncoll.edu. 
followed with meaningful, substantive actions to help meet the goals, then pledges are examples of symbolic politics-commitments based on rhetoric rather than clear objectives to help realize the goal.

This paper investigates what happened in Costa Rica after elites announced this pledge in order to examine the extent to which the pledge has moved beyond a symbolic political act to produce substantive effects. Investigating Costa Rica’s pledge presents the opportunity to analyze an environmental action in a developing country that is one of the smallest contributors to global greenhouse gas emissions (Brechin, 2016) but that is nonetheless pursuing an ambitious mitigation response. Prior to its work on carbon neutrality, Costa Rica generated about $90 \%$ of its electricity from renewable sources (Nandwani, 2006) and had pursued several other notable initiatives, including abolishing its army, developing an extensive national parks program, and mediating a regional conflict (Evans, 1999). Therefore, the analysis of the post-pledge context should uncover some important lessons for those interested in the politics of this nation and its response to climate change.

In addition, exploring the aftermath of Costa Rica's pledge may offer insights that are important beyond this case. The adoption of the 2015 Paris Agreement, which includes a pledge-and-review structure for nations' nationally determined contributions (NDCs) (Dimitrov, 2016; Keohane \& Oppenheimer, 2016), has brought national pledges to the center stage of global climate politics. The lessons learned from this study of Costa Rica's pledge, made nearly 10 years before the Paris Agreement, may reveal insights into what may happen in the years following other nations' NDCs.

The first section below provides a literature review on the concept of symbolic politics. The next section provides background information on the circumstances under which Costa Rica's pledge was made. Then, after a discussion of the methods, the paper discusses three key dimensions of the post-pledge context. The discussion reviews the lessons learned from this case and the conclusion discusses the implications these findings have for broader research.

\section{Literature review}

Previous research on symbolic politics has focused on several areas, including the characteristics of symbolic politics, the circumstances under which they are used, and how symbolic politics differ from other politics. According to Matten (2003), what makes a piece of legislation symbolic is that, from the start, it is known that the stated legislative goal cannot be achieved. Symbolic politics are either "sheer rhetoric" or they are put together in a manner that makes it impossible for their goals to be met (Matten, 2003, p. 216). In this view, symbolic politics are not accidental-it is clear from the start that their objectives will not be fulfilled. 
For Ovink et al. (2016), leaders use symbolic political acts as a means to send messages to particular audiences. More specifically, they may use symbolic politics to attract voters who care about a particular issue, respond to an issue on which there has been little other action, and/or to illustrate their positions on an issue or on a group of people (Ovink et al., 2016). For Wysong et al. (1994), symbolic politics allow leaders to show that they have responded to a socially constructed threat. The DARE (Drug Abuse Resistance Education) educational program in the US, which was designed to keep kids off drugs, is an example of symbolic politics since the program was used to offer "reassurance" that leaders had responded to the drug "problem" (Wysong et al., 1994, p. 462). Similarly, Newig (2007) finds that symbolic legislation is often used when attention around a social issue is very high. Symbolic politics are also used for issues that lack clear solutions, have high costs, involve value conflicts, have an uneven spread of relevant information, and/or that are highly complex (Newig, 2007, p. 291).

Symbolic politics, or as Baker (2007, p. 298) puts it, "empty rhetoric," have been compared to their "genuine and consequential" policy peers, or those that influence human life. Gusfield (1967) contrasted the instrumental and the symbolic functions of political acts. Certain political acts have an instrumental function in that they exert a "direct influence" on human activity (Gusfield, 1967, p. 176). It is through enforcement that these laws or policies come to have an instrumental function. In contrast, symbolic acts are significant because of the meaning people attribute to them. Symbolic acts do not have to be enforced, or perhaps cannot be enforced, but still exert an influence through what they represent. Anderson (2003) adds that policies can be categorized based on the benefits they distribute. On the one hand, material policies confer advantages or disadvantages on people, while on the other hand, symbolic politics do neither, and instead appeal to "cherished values," such as “peace, patriotism, and social justice” (Anderson, 2003, p. 16).

Researchers have come to show, however, that all policies have characteristics of both the symbolic and the material, with some invoking the idea of a continuum of action types, ranging from the symbolic to the substantive (Anderson, 2003; Kim \& Lyon, 2013). Newig (2007) agrees, but instead of using a continuum, he proposes a two-axis chart for categorizing policies. Policies vary along two dimensions-their issue-related substantive effectiveness and their political-strategic effectiveness. The former dimension captures the degree to which a piece of legislation can resolve an issue, while the latter captures a piece of legislation's political consequences. While the stated intention of legislation is often that it is for addressing real-world conditions (issue-related substantive effectiveness) it is also often used for political ends, such as demonstrating leaders' commitments to an issue or meeting the "emotional needs" of a constituency (political-strategic effectiveness) (Newig, 2007, p. 279). Political acts have both dimensions of effectiveness but differ in the degree to which they have more or less of each. 
Returning to the case of Costa Rica, this paper investigates whether this nation's pledge has moved beyond a symbolic commitment and, if so, how? In order to do this, the next section presents background information on the circumstances under which Costa Rica's initial pledge was made.

\section{Background information on Costa Rica's pledge}

Óscar Arias Sánchez, Nobel Peace Prize Laureate, began his second (non-consecutive) term as President of Costa Rica in May 2006. In a decree released on 7 December 2006, the Office of the President of Costa Rica launched a presidential initiative entitled Peace with Nature (Executive Power, 2006). This document provides an overview of the new government's concern with global environmental issues, stating that the government is broadly pursuing an aim of establishing active and perpetual peace with nature (Executive Power, 2006, p. 2). The decree states that because of Costa Rica's notable work in issues such as health, education, and democracy, the country has the moral authority to assume active leadership at the international level to promote a larger political responsibility oriented toward resolving the problems that affect the planetary ecosystem (Executive Power, 2006, p. 2). This document invokes themes from Arias's first presidency, when he received a Nobel Peace Prize (Fletcher, 2013). By calling the initiative Peace with Nature, leaders were trying to "recreate the image of peace" that existed during Arias's first presidency $\left(\mathrm{G}^{2}\right)$ and help Costa Rica once again receive international recognition for undertaking ambitious, progressive reforms (G5).

The government and an appointed leader assembled a 30-person coalition to advance the Peace with Nature initiative's goals. This coalition included former and current government officials (including the President and both the Minister and Vice Minister of the Environment), leaders from industry, and Costa Rican scientists, including Alvaro Ugalde and Mario Boza, leaders from the development of Costa Rica's national parks (Evans, 1999). The committee also included scientists from the United States with a history of conducting research in Costa Rica (G6; Ponchner \& Vargas, 2007). While the specific aims of the Peace with Nature coalition are not articulated in the December 2006 decree, in the months following, the members of the coalition decided to pursue three main objectives: the creation of a fund for the national parks, carbon neutrality, and the greening of the public sector (G6). One interviewee explained that carbon neutrality was a frame within which all of these aims fell, since it encourages lower rates of consumption (C1). Thus, from the start the carbon neutral pledge was embedded in a broader political

2 To cite interview data throughout the text, references to data are tagged with a letter and a numeral. The letter represents the field from which the interviewee was drawn and the numeral represents the interviewee's order in the process of fieldwork. Thus G3 indicates the third interviewee from government. For further explanation, see the "Methods" section. 
agenda (Sherwood, 2007). The Minister of the Environment, Dr. Roberto Dobles, announced the Peace with Nature initiative and the carbon neutral pledge at the February 2007 United Nations Environment Programme's (UNEP) governing council meeting in Nairobi, Kenya. Dr. Dobles became the president of the governing council at this meeting. It was a strategic decision to highlight Costa Rica's domestic work on climate change at this international forum (G2; G4). In his opening remarks Dobles (2007, p. 7) said:

Coming from Costa Rica, a country where the sustainable management of natural resources has been a state policy and where peace has also been part of our way of life (we abolished the armed forces in 1948) I am very honored to serve as President of UNEP's Governing Council and Global Ministerial Environment Forum. We have now declared Peace with Nature in our country and this concept is now at the center of our development and trade policy.

The pledge announcement was an opportunity to highlight that Costa Rica was, once again, leading the way on important social and environmental issues, this time with climate mitigation (Flagg, 2018). A top government official from the Arias administration explained that the adoption of the carbon neutral pledge did not require the approval of the unicameral legislative assembly in Costa Rica because the pledge is a policy, not a law (G4). Therefore, no entity is required to become carbon neutral but every institution has the opportunity to do so. Interviewees explained that there was a general environmental and climate awareness in government, industry, and academia before 2007 and the pledge capitalized on this enthusiasm (G3; G5). There was no external, supranational governing body that oversaw Costa Rica's pledging process or that has enforced the degree to which Costa Rica is on track to meet its voluntary commitment by 2021, so any enforcement of the implementation of carbon neutral pledges would have had to come from the domestic context. The same appears to be true for the other nations that have made identical announcements to become carbon neutral (Flagg, 2015). This feature of carbon neutral pledges has led Kythreotis $(2015$, p. 807) to state that carbon neutral pledges "only mean something if they are translated into firm political action."

More than 10 years have now passed since the initial pledge announcement. If the pledge was more than a symbolic maneuver, it should be possible to observe some post-pledge shifts in Costa Rica's environment and society. Indicators of these shifts may include changes in 1) carbon emissions, 2) political planning and procedures, and 3) institutional practices. The next section describes the research methods used to investigate whether there is evidence of these changes. 


\section{Methods}

Data for this case study consist of government documents and fieldnotes from interviews. Data were woven into a narrative to trace the process between the announcement of the pledge and 2015 . The point is to analyze data "on the causal mechanisms, or processes, events, actions, expectations, and other intervening variables" during this time period (Bennett \& George, 1997, p. 5). Fieldwork in Costa Rica was conducted in August 2013 and July 2015. Conducting fieldwork over time enabled the initial interviews to guide archival research, and then to use that archival research to guide the second, more targeted, set of interviews. A possible drawback of this approach, however, is that it did not enable the deep immersion that would have been possible in one long fieldwork visit. Archival documents were collected before, during, and after fieldwork and include politicians' speeches, newspaper articles, government decrees and laws, and reports from international institutions (i.e., the UNFCCC [United Nations Framework Convention on Climate Change]). Interviews with representatives from government, science, industry, and civil society were designed to fill in the gaps from the archival research, and to explore the process by which the pledge was adopted. During interviews, participants were also eager to speak about what has happened since the pledge was announced. Interviewees in government include government officials and government consultants who worked on carbon neutrality. Given that the respondents of interest were "hard-toreach," but also "somewhat interconnected," a snowball sample (Schutt, 2009, p. 174) was used to recruit respondents. Each interviewee was asked to recommend additional respondents.

Table 1 provides the date of interviews and interviewees' affiliations. In total, 22 interviews were conducted with 20 respondents. Because the fieldwork was conducted in research trips separated by two years, two key informants were interviewed again during the second trip, to follow up on information gathered in the first interview, inquire about the status of the carbon pledge, and acquire contact information for additional respondents. Interviewees were recruited on the basis that they were involved in the process leading up to the pledge or had worked on carbon neutrality after the pledge. These people were identified from the ongoing analysis of archival documents or from other respondents. On the recommendation of interviewees, the sample includes a representative from AECID (the Spanish Agency for International Development Cooperation), which was involved in the carbon neutrality initiative, several academics (some of whom were involved in the initial work on carbon neutrality, and others who have written about the pledge), and a representative from INTECO (the Costa Rican Institute of Technical Norms). Similar to Speck's (2010) findings, interviewees were knowledgeable and concerned about anthropogenic climate change. 
Table 1: Interviewees by date, and primary and additional domains of public life.

\begin{tabular}{|c|c|c|}
\hline Date & Primary domain & Additional domains \\
\hline \multicolumn{3}{|l|}{ Industry } \\
\hline 8/1/2013 (Skype) & I1 (Bananas) & - \\
\hline 7/8/2015 & I2 (Bananas) & - \\
\hline 7/20/2015 (Skype) & I3 (Hotel) & - \\
\hline $7 / 21 / 2015$ & 14 (Hotel) & - \\
\hline $7 / 21 / 2015$ & 15 (Coffee) & - \\
\hline \multicolumn{3}{|l|}{ Government } \\
\hline $8 / 21 / 2013$ & G1 & - \\
\hline 8/26/2013 \& 7/6/2015 & $\mathrm{G}^{*}$ & Science \\
\hline $7 / 8 / 2015$ & G3 & Academia (Economics) \\
\hline $7 / 13 / 2015$ & G4 & Industry \\
\hline 7/14/2015 & G5 & - \\
\hline $7 / 16 / 2015$ & G6 & Science, civil society, academia \\
\hline \multicolumn{3}{|l|}{ Science } \\
\hline 8/22/2013 \& 7/10/2015 & $\mathrm{S} 1^{*}$ & Academia \\
\hline 8/28/2013 & S2 & Academia \\
\hline $7 / 22 / 2015$ & S3 & Government \\
\hline \multicolumn{3}{|l|}{ Civil society } \\
\hline $7 / 13 / 2015$ & C1 & Science, government \\
\hline $7 / 20 / 2015$ & $\mathrm{C} 2$ & - \\
\hline \multicolumn{3}{|l|}{ Academia } \\
\hline $8 / 27 / 2013$ & A1 & Academia \\
\hline 7/9/2015 & A2 & Academia \\
\hline \multicolumn{3}{|l|}{ Other } \\
\hline $7 / 14 / 2015$ & AECID-1 & - \\
\hline $7 / 15 / 2015$ & INTECO-1 & - \\
\hline
\end{tabular}

Note: *Interviewed twice. Respondents from: I = Industry, G = Government, S = Science, A = Academia, $\mathrm{C}=$ Civil society. AECID: the Spanish Agency for International Development Cooperation. INTECO: Costa Rican Institute of Technical Norms.

Source: Author's summary of fieldwork process. 
Interviews were conducted in Spanish and/or English, based on each respondent's preference. Notes from each interview were typed into field notes as soon as possible afterward. The author conducted all interviews and completed all translations. When it was not possible to capture direct quotations, the best account possible of interviewees' words is provided and field notes are cited. Table 1 is divided up by the interviewees' domain of public life (industry, government, science, civil society, etc.) from which they were recruited. Many interviewees, especially those in government, science, and civil society have moved among these sectors and academia, reflecting a long-standing pattern in Costa Rica (Hrabanski et al., 2013, p. 130). The second column lists interviewees based on the role that was the most meaningful to them in describing their involvement with work on carbon neutrality. This is how they are referenced throughout the text (i.e., G1 for first government official interviewed). Any additional affiliations are listed in the final column of Table 1.

A general outline of events was constructed, first from an analysis of the archival documents. Then insights from interview fieldnotes were added. This strategy illuminated the process that followed the announcement of the pledge. Process tracing "focuses on the unfolding of events or situations over time," and this strategy was used for analyzing the data (Collier, 2011, p. 824, emphasis in original). The following section explains three dimensions of the post-pledge context in Costa Rica that emerged from this analysis.

\section{Results}

The findings reveal that three areas of public life began to shift after the pledge was announced: 1) government action and changes in emissions; 2) sub-national action on carbon neutrality; and 3) issues associated with monitoring and verifying emissions.

\section{Government action and changes in emissions}

Carbon neutrality was a political decision, and thus was made by political leaders and top government advisors. A plan to achieve carbon neutrality was not formalized at the time of the pledge announcement (C1; INTECO-1), but one of the first consequences of the pledge was that it created the political pressure to formulate detailed plans to achieve it. Following the Minister of the Environment's announcement of the pledge at the UNEP meeting, experts from natural science, public policy, and government began to write the national plan on carbon neutrality. This plan, known as "The National Strategy on Climate Change" (Government of Costa Rica, Ministry of the Environment, Energy, and Telecommunications 
[MINAET], ${ }^{3}$ 2009), was finalized in 2009. The plan includes both national and international agendas for responding to climate change, as well as a strategy for carbon neutrality. This part of the plan explains that as part of the Peace with Nature initiative, Costa Rica has made the following voluntary commitment: by 2021, Costa Rica will contribute nothing to global warming or to the deterioration of the air that we breathe (MINAET, 2009, p. 80). Additional text and figures clarify that the aim is to produce net zero total emissions by 2021.

One former government official stressed the importance of using international standards in this National Strategy because this would enable comparisons between Costa Rica and other countries. To elaborate the high regard to which he held standards (and data more generally), he quoted William Deming, a statistician from the United States, as saying: "In God we trust. Everyone else uses data" (G4). His point was that a carbon neutral national strategy needed to have metrics that people could trust. The data on Costa Rican forests and emissions for the national plan came from several institutions, including FONAFIFO (the National Forestry Financing Fund) and the National Meteorological Institute (MINAET, 2009).

One piece of evidence that would indicate that Costa Rica's pledge has become something more than a purely symbolic commitment would be a decline in the country's carbon emissions since 2007. A decline in emissions would provide some evidence for the pledge's issue-related substantive effectiveness (Newig, 2007). Table 2 displays Costa Rica's absolute and per capita carbon emissions from 2005 to 2014, the most recent year for which data are available (World Bank, 2019). These data show that both absolute and per capita carbon emissions declined between 2008 and 2010, before rebounding slightly in 2011 .

Table 2: Carbon dioxide $\left(\mathrm{CO}_{2}\right)$ emissions from Costa Rica.

\begin{tabular}{|l|l|l|}
\hline Year & $\mathrm{CO}_{2}$ emissions (kilotons) & $\mathrm{CO}_{2}$ emissions (metric tons per capita) \\
\hline 2005 & 6868.29 & 1.62 \\
\hline 2006 & 7099.31 & 1.65 \\
\hline 2007 & 8122.41 & 1.86 \\
\hline 2008 & 8129.74 & 1.84 \\
\hline 2009 & 7902.39 & 1.76 \\
\hline 2010 & 7568.69 & 1.67 \\
\hline 2011 & 7741.04 & 1.68 \\
\hline 2012 & 7766.71 & 1.67 \\
\hline 2013 & 7598.02 & 1.61 \\
\hline 2014 & 7759.37 & 1.63 \\
\hline
\end{tabular}

Source: World Bank (2019).

3 Telecommunications left MINAET in 2013. 
Though this decline in emissions would seem to suggest that Costa Rica's pledge helped foster emissions reductions, analyzing changes in emissions alone as evidence of the pledge's move from symbolic to substantive should be done with caution. First, the observed dip in emissions is attributable more to the effects of the global recession, rather than to any concerted efforts to reduce emissions. Globally, greenhouse gas emissions and carbon dioxide emissions specifically dropped from 2008 to 2009, before increasing again in 2010 (Climate Watch, 2019). Second, even under ideal conditions, there would be a lag between a policy announcement and changes in national emissions. These two limitations for analyzing changes in emissions means that the analysis of the post-pledge context must examine broader social, political, and institutional changes that can be more directly attributed to the pledge announcement. The next two sub-sections describe some of these changes.

\section{Sub-national action}

Costa Rica's carbon neutral commitment is a national goal, but work on carbon neutrality has happened in institutions at sub-national scales. When asked what the authors of the national plan had in mind when they envisioned Costa Rica as a carbon neutral country, an official from the Department of Climate Change said they did not think about carbon neutrality at the level of the nation-that would be, as he put it, "too abstract." Rather, they thought about schools, businesses, and institutions becoming carbon neutral, adding that "everyone has homework" when it comes to carbon neutrality (G2).

Unlike New Zealand's carbon neutral public service program (Birchall, 2014), the work on carbon neutrality in Costa Rica has primarily happened in the private sector. Following the carbon neutrality announcement, the Minister of the Environment met with various Costa Rican industries. Government thought carbon neutrality was "good business" since working toward the goal would save businesses money and be attractive to consumers, "especially the Europeans" as one former official explained (G4). In elaborating on this point, he explained that Costa Rica ships many exports to Europe and that if these products could continue to meet high standards but also be certified as carbon neutral, consumers would want to buy them. He used bananas as a specific example. But he also believed that changes could be made to goods sold domestically to tourists in Costa Rica, such as hotel rooms (G4). In short, he assumed consumers would make decisions to buy carbon neutral products once they were available.

There are various chambers of business in Costa Rica that oversee and represent individual businesses in an economic sector and the Minister of the Environment started by visiting several chambers of industry including bananas, hotels, banks, and airlines (I1; G4). The government "invited" industries to join the efforts on carbon neutrality (G1), and interviewees explained that industry, both at large and specific businesses, was receptive to the idea (I2; I3; I4; G5; S1; C1). 
Following these meetings, some sub-national constituents began to make their own carbon neutrality pledges. For example, an interviewee from CORBANA (the National Banana Corporation), a public, non-state overseer of Costa Rica's banana industry, explained that by the time the Minister of the Environment arrived to talk with the banana industry, the commission of banana producers and government officials was already discussing carbon neutrality for the industry. One year later, the commission produced and shared with the government a report that outlined their efforts to become carbon neutral. The government then gave this plan to individual banana producers so they knew about strategies and plans to become carbon neutral. Overall, the respondent from CORBANA claimed that industry generally "supported the idea" of carbon neutrality (I2).

Interviewees from hotels and the coffee industry also reported being receptive to carbon neutrality and explained that working toward the goal had multiple benefits. As an employee from Café Britt, a major coffee company, explained, Britt was one of the first Costa Rican companies to become carbon neutral (Department of Climate Change, n.d.) because "we really believe it's something we can work with" (I5). He added that Café Britt sees the environmental benefits from working on carbon neutrality and explained that carbon neutrality might give the company an advantage on the international market by appearing environmentally friendly.

A representative from a luxury hotel near the Arenal volcano explained that carbon neutrality was about doing the right environmental thing and making money (I3). The hotel started working on carbon neutrality right after the government's announcement because the hotel has "a lot of primary forest" around it and it wanted to maintain that. But, she added, it's "a business strategy also." She explained that the hotel is a luxurious one, and that "everything here is green," suggesting that carbon neutrality is also about value. Tourists are "attracted to that idea," and "most people are looking for that" when they book a vacation. She added that the hotel hired an employee to calculate the hotel's emissions and create an inventory of its greenhouse gas emissions. The hotel started this process in 2007, finished its inventory in 2011, and then sent it to the Ministry of the Environment.

The general manager of a hotel in San José who claimed that the hotel was briefly carbon neutral had a similar explanation about the hotel's motivations for carbon neutrality. He said that in 2010, the hotel became carbon neutral, but at the time of the interview (July 2015) the hotel was no longer considered carbon neutral nor was it working to become carbon neutral because it was undergoing significant renovations. The hotel pursued carbon neutrality out of a sense of "social responsibility" (I4). The hotel had previously pursued social programs to benefit children and the environment so the carbon neutral pledge extended this tradition. As he explained, the hotel has to be a "place where people want to come." He added, we "want the [carbon neutral] stamp" (an indicator from the government signifying that the business is carbon neutral) and we want to "be an example for other 
companies." For these industry representatives, carbon neutrality was important to each business's identity and good for marketing, since the stamp illustrates its environmental achievements to customers.

\section{Issues of monitoring and verification}

When the Minister of the Environment met with industry representatives, these representatives asked about the process for becoming carbon neutral (G4). To determine the standards for carbon neutrality, in 2009, the Ministry of the Environment solicited help from INTECO to create a carbon neutral norm. INTECO verifies that Costa Rica is in compliance with norms from international organizations such as the International Organization for Standardization and standardizes voluntary norms that are pursued at the national level (ISO, n.d.). An employee from INTECO explained that INTECO's work on carbon neutrality was different from its usual work because a norm did not exist for how a country could achieve this goal (INTECO-1). There was, however, a norm from the United Kingdom detailing how groups at smaller levels of scale could become carbon neutral. This norm, PAS 2060 (Publicly Available Specification), was developed by the British Standards Institution in 2010 (Ecoact 2019). INTECO used this norm as the basis for its carbon neutrality norm. As a university official put it, "This [carbon neutrality] is something we built," (S1) emphasizing his belief that it was pioneering for Costa Rica to apply PAS 2060 to a nation.

According to INTE.12.016, the norm INTECO developed, organizations must follow three steps to become carbon neutral: calculate, reduce, and compensate (INTECO-1). First, an organization identifies the sources of its emissions, calculates emissions, and develops an inventory of annual tons of carbon dioxide $\left(\mathrm{CO}_{2}\right)$ emissions. A business can hire a consultant to do this inventory or enroll an employee in a course that INTECO offers. Second, the organization reduces emissions. The carbon neutrality norm does not specify how or what a company should do; the company must select carbon-reducing actions on its own. But even after taking such actions, an organization will inevitably still release emissions. Thus, third, an organization compensates for its remaining emissions to bring total emissions to net zero. Here, a company pays for its emissions by purchasing carbon offsets through FONAFIFO.

When asked to compare this Costa Rican process of achieving carbon neutrality to the UK norm it was based on (PAS 2060), the respondent from INTECO said it was "similar." The three steps are the same, but in the United Kingdom the norm for sub-national groups to become carbon neutral was not paired with the national objective of becoming carbon neutral (INTECO-1). 
After a company completes these steps, INTECO or Earth University verifies that the company emits net zero emissions and is evaluated annually to ensure its continued compliance (G4; S1; INTECO-1). A business can lose the carbon neutral stamp. A third organization, ECA, the Costa Rican Entity of Accreditation (ECA, 2011) accredits INTECO and Earth University (INTECO-1). Upon verification that a product or company has "zero impact" on the climate, the Ministry of the Environment and Energy awards the business a carbon neutral stamp (MINAET, 2009, p. 83).

\section{Discussion}

The carbon pledge has undergone changes but remains salient in Costa Rican politics. In 2010, the Peace with Nature coalition disbanded but was replaced with the Department of Climate Change, which is in charge of the carbon neutrality goal (Republic of Costa Rica, 2009, p. 31). As of July 2015, the staff in this department still expressed a commitment to making Costa Rica a carbon neutral country (G2). President Luis Guillermo Solís (2014-2018) first intended to push back the target date of 2021 (Fendt, 2014) but then committed to meet the goal by that date ("Costa Rica pledges," 2017). Recently elected President Carlos Alvarado Quesada almost immediately pledged to discontinue the use of any fossil fuels in transportation, the country's largest contributor to greenhouse gas emissions, by the year 2021 (Embury-Dennis, 2018).

In its Intended Nationally Determined Contribution (INDC), submitted ahead of the 2015 Conference of the Parties (COP) meeting in Paris, the Costa Rican government "reaffirm[ed] its aspiration of becoming a Carbon Neutral economy starting year 2021" (Government of Costa Rica, Ministry of Environment and Energy, 2015, p. 2). The document adds that the aim of carbon neutrality is to make emissions by 2021 "comparable to total emissions in 2005," a notable difference from the 2009 document, where this baseline year was not discussed (Government of Costa Rica, Ministry of Environment and Energy, 2015, p. 3). Later in the INDC, the government describes its ambitious long-term goal to "accomplish zero net emissions by 2085" (Government of Costa Rica, Ministry of Environment and Energy, 2015, p. 10). At this time, it is unclear why 2085 was chosen as the new target date for achieving carbon neutrality, but other sources also affirm the country's commitment to produce net zero carbon emissions by 2085 (Climate Action Tracker, 2015; Replogle, 2015). It seems as though shorter-term emissions goals have been made for 2021, and longer-term goals have been set for 2085. Although the timeline for achieving carbon neutrality appears to have shifted significantly, support for de-carbonization persists. 
This analysis of Costa Rica's pledge reveals that the pledge has moved beyond the merely symbolic (Bluhdorn, 2007) and has fostered some shifts in Costa Rican society. However, at this time, there is more evidence of political and institutional changes that are attributable to the pledge, than of changes in carbon emissions. The announcement of Costa Rica's pledge was an almost entirely symbolic act. By the time politicians began to discuss carbon neutrality, 20 years had passed since President Arias had been awarded a Nobel Peace Prize, an action that brought significant global attention and economic advantages to Costa Rica. Initially the goal was to achieve carbon neutrality by 2021, the bicentennial anniversary of Costa Rica's independence from Spain (MINAET, 2009). From the start, the pledge was associated with Costa Rican national identity and highlighted the country's unusual actions to a global audience.

Other research has found that the symbolic characteristics of pro-environmental actions can motivate adoption of these actions. Noppers et al. (2014, p. 60) find that people are more likely to pursue "green" actions when they believe these actions will improve their "self-identity and social status." Though these authors' conclusions are drawn from research conducted on individual people, we see a similar dynamic happening at the national level in Costa Rica. The symbolic pledge of becoming the first nation to become carbon neutral, during a historical moment (2006-2007) of global inaction on climate change (Roberts \& Parks, 2007), was a way to shape the global community's ideas about what kind of place Costa Rica is and display elites' own ideas about the nation they inhabit.

The pledge announcement was a highly symbolic event. At the time of the announcement, a clear plan detailing how to become carbon neutral did not yet exist. But the announcement of the pledge was a single moment in time that was followed by an interest in confronting the question of how to reduce emissions. The state led in this effort. The data drawn upon here do not show evidence of a coordinated, government-led effort to overhaul the Costa Rican economy in an ecologically modern way (Buttel, 2000; Mol \& Sonnenfeld, 2000). However, elites organized and created a way for institutions to pursue carbon neutrality on their own. The Department of Climate Change (n.d.) reports that 41 companies had been verified as carbon neutral by the end of 2015, and by the end of 2016, this number had climbed to 64 . Another four companies have completed their carbon emission inventories and are working toward becoming carbon neutral (Department of Climate Change, n.d.).

The pledge has led to some "green" capacity building, an indicator of issue-related substantive effectiveness (Newig, 2007). There are some similarities here to research done on voluntary agreements or voluntary regulations. The government of Colombia, for example, has pursued voluntary regulation agreements with industry that create incentives for compliance with an environmental initiative rather than penalize for non-compliance (Blackman et al., 2013). While Blackman et al. 
(2013, p. 363) find that Colombian industry's compliance with voluntary environmental agreements has been "spotty," they also find that the agreements have fostered "environmental management capacity" in these industry groups.

Costa Rica’s carbon pledge has fostered "green" capacity building in higher education, industry, and government. For example, Earth University not only declared itself carbon neutral but also stated its intention to become an entity that certified other organizations' greenhouse gas emissions in 2007 (Vargas, 2007) and formed its carbon neutral program to certify companies as carbon neutral in 2008. The hotels working on carbon neutrality hired personnel to calculate their emissions. Also, while the group known as Peace with Nature disbanded in 2010, the government transformed this committee's work into the Department of Climate Change. And clearly, Costa Rica's work on carbon neutrality from the mid-2000s influenced its INDC ahead of the Paris 2015 COP.

While the pledge has moved beyond entirely symbolic, there was room to make it much more substantive. The act of "inviting," as one interviewee put it (G1), businesses to join the national efforts on carbon neutrality allowed government to tout its mitigation efforts to international audiences, but freed it from having to hold industries accountable to their commitments. In short, the pledge is a winwin scenario for the government. Several interviewees, even those most intimately involved with the work on carbon neutrality, were critical of the government's shortcomings on the pledge (G6; C1).

The findings from this case suggest a new way for researchers to consider symbolic politics. This analysis reveals that research on symbolic politics has thus far paid too little attention to the issue of time, or more specifically, to how political acts can change from symbolic to (more) substantive with the passing of time. Researchers have made helpful strides in thinking about the characteristics of symbolic politics and the circumstances under which they are adopted (Gunnlaugsson \& Galliher, 1986; Gusfield, 1967; Matten, 2003; Newig, 2007; Ovink et al., 2016; Wysong et al., 1994). Thinking about how symbolic politics are different, or not so different, from other kinds of politics has evolved from the use of categories (symbolic or not), to continuums (more or less symbolic), to two-axis charts (Newig, 2007). But a consistency throughout this work so far has been that political actions are treated as static over time. Political acts begin and end as either more or less symbolic. Prior work has not paid enough attention to the question of how symbolic political decisions can change when they are placed in a societal context that has to decide whether to grapple with them, and if so, how. This research shows that while Costa Rica's pledge began as symbolic, it has taken on some substance over time. With the use of process tracing, which is especially helpful for analyzing the "unfolding of events or situations over time" (Collier, 2011, p. 824, emphasis in original), this research shows that while the initial pledge announcement was highly symbolic, the pledge has, over time, become something different. This means that this pledge merits further study over time. 


\section{Conclusion}

Though the findings from this work are limited to the case of Costa Rica, it is very possible that the findings have relevance more broadly in the aftermath of the Paris Agreement. The pledge-and-review structure of the Paris Agreement now puts nations' individual pledges front and center in climate politics. Despite the inability of even complete implementation of nations' pledges to limit global temperature rise to 2 degrees Celsius (Rogelj et al., 2016), the findings from this research suggest that national pledges may lead to important "green" capacity building and both institutional and political changes that may, over time, lead to emissions reductions.

Future research could investigate potential parallels between the aftermath of Costa Rica's pledge and the aftermath of other nations' pledges. An important question for the future is whether INDCs started as symbolic, and whether they have become more substantive over time. A related question to investigate is whether certain political contexts are more conducive of helping change symbolic pledges to substantive commitments. Additional research is needed to investigate these and related questions.

\section{References}

Anderson, J. E. (2003). Public policymaking: An introduction. Fifth edition. Boston, MA: Houghton Mifflin Company.

Baker, S. (2007). Sustainable development as symbolic commitment: Declaratory politics and the seductive appeal of ecological modernisation in the European Union. Environmental Politics, 16(2), 297-317. doi.org/10.1080/09644010701211874.

Bennett, A. \& George, A. L. (1997, October). Process tracing in case study research. Paper presented at the MacArthur Foundation Workshop on Case Study Methods, Belfer Center for Science and International Affairs (BCSIA), Harvard University. Retrieved from www.uzh.ch/cmsssl/suz/dam/jcr:00000000-5103-bee3-0000-000059b16b9d/05.19. bennett_george.pdf.

Birchall, J. (2014). New Zealand's abandonment of the carbon neutral public service programme. Climate Policy, 14(4), 525-535. doi.org/10.1080/14693062.2014.877224.

Blackman, A., Uribe, E. van Hoof, B., \& Lyon, T. P. (2013). Voluntary environmental agreements in developing countries: The Colombian experience. Policy Sciences, 46, 335-385. doi.org/10.1007/s11077-013-9176-z.

Bluhdorn, I. (2007). Sustaining the unsustainable: Symbolic politics and the politics of simulation. Environmental Politics, 16(2), 251-275. doi.org/10.1080/096440107012 11759. 
Brechin, S. R. (2016). Climate change mitigation and the collective action problem: Exploring country differences in greenhouse gas contributions. Sociological Forum, 31(S1), 846-861. doi.org/10.1111/socf.12276.

Buttel, F. H. (2000). Ecological modernization as social theory. Geoforum, 31(1), 57-65. doi.org/10.1016/s0016-7185(99)00044-5.

Climate Action Tracker. (2015). Costa Rica. Retrieved from climateactiontracker.org/ countries/costarica.html.

Climate Watch. (2019). Costa Rica. Retrieved from www.climatewatchdata.org/countries/ CRI/.

Collier, D. (2011). Understanding process tracing. PS: Political Science and Politics, 44(4), 823-830. doi.org/10.1017/s1049096511001429.

Costa Rica pledges carbon neutrality by 2021. (2017, January 20). Retrieved from www. climateactionprogramme.org/news/cost_rica_pledges_carbon_neutrality_by_2021.

Department of Climate Change. (n.d.). Businesses and organizations toward carbon neutrality 2021. Retrieved from cambioclimatico.go.cr/recursos/empresas-ppcn/.

Dimitrov, R. S. (2016). The Paris agreement on climate change: Behind closed doors. Global Environmental Politics, 16(3), 1-11. doi.org/10.1162/glep_a_00361.

Dobles, R. (2007, February 5). Statement of acceptance by president of the UNEP governing council/global ministerial environment forum under agenda item 2(a) election of officers. Retrieved from www.unep.org/GC/GC24/docs/Statement-NewGCPres05Feb. pdf (site discontinued).

Ecoact. (2019). White paper PAS 2060: The first standard for carbon neutrality. Retrieved from info.eco-act.com/en-gb/pas-2060-factsheet.

Ehrhardt-Martinez, K., Rudel, T. K., Norgaard, K. M., \& Broadbent, J. (2015). Mitigating climate change. In R. E. Dunlap \& R. J. Brulle (Eds.), Climate change and society: Sociological perspectives (pp. 199-234). New York, NY: Oxford University Press. doi.org/ 10.1093/acprof:oso/9780199356102.003.0007.

Embury-Dennis, T. (2018, May 10). Costa Rica to ban fossil fuels and become world's first decarbonized society. The Independent. Retrieved from www.independent.co.uk/ environment/costa-rica-fossil-fuels-ban-president-carlos-alvarado-climate-change-globalwarming-a8344541.html.

Ente Costarricense de Acreditacion (ECA). (2011). Ente Costarricense de Acreditacion. Retrieved from www.eca.or.cr/.

Evans, S. (1999). The green republic: A conservation history of Costa Rica. Austin, TX: University of Texas Press. 
Executive Power. (2006). Declara de interés público la iniciativa "Paz con la Naturaleza" impulsada por la presidencia de la república [The presidency of the republic declares, in the public interest, the initiative "Peace with Nature."] Retrieved from www2.eie.ucr. ac.cr/_jromero/sitio-TCU-oficial/normativa/archivos/leyes_nac/Declara_de_Interes_ Publico_la_Iniciativa_Paz_con_la_Naturaleza.pdf.

Fendt, L. (2014, March 8). Solís to suspend Costa Rica's carbon neutrality goal. The Tico Times. Retrieved from www.ticotimes.net/2014/03/08/solis-to-suspend-carbon-neutrality-goal.

Flagg, J. A. (2015). Aiming for zero: What makes nations adopt carbon neutral pledges? Environmental Sociology, 1(3), 202-212. doi.org/10.1080/23251042.2015.1041213.

Flagg, J. A. (2018). Carbon neutral by 2021: The past and present of Costa Rica's unusual political tradition. Sustainability, 10(2), 296-309. doi.org/10.3390/su10020296.

Fletcher, R. (2013). Making "Peace with Nature": Costa Rica's campaign for climate neutrality. In C. Roger, D. Held, \& E. Nag (Eds.), Climate change governance in the developing world (pp. 155-173). London, UK: Policy Press.

Fukuda, K. \& Tamura, K. (2010). An analysis of non-annex 1 Parties NAMAs: Challenges for designing international support and implementing an effective MRV framework (Working paper 2010-001). Retrieved from pub.iges.or.jp/modules/envirolib/upload/3040/attach/ cc-working-paper2010-001.pdf.

Government of Costa Rica, Ministry of Environment and Energy. (2015). Costa Rica's intended nationally determined contribution. Retrieved from www4.unfccc.int/sites/submissions/ INDC/Published\%20Documents/Costa\%20Rica/1/INDC\%20Costa\%20Rica\%20 Version\%202\%200\%20final\%20ENG.pdf.

Government of Costa Rica, Ministry of Environment, Energy, and Telecommunications (MINAET). (2009). The national strategy on climate change. Retrieved from cambioclimaticocr.com/2012-05-22-19-42-06/estrategia-nacional-de-cambio-climatico (site discontinued).

Gunnlaugsson, H. \& Galliher, J. F. (1986). Prohibition of beer in Iceland: An international test of symbolic politics. Law and Society Review, 20, 335-353. doi.org/10.2307/3053579.

Gusfield, J.R. (1967). Moral passage: The symbolic process in public designations of deviance. Social Problems, 15(2), 175-188. doi.org/10.1525/sp.1967.15.2.03a00040.

Hrabanski, M., Bidaud, C., Le Coq, J., \& Meral, P. (2013). Environmental NGOs, policy entrepreneurs of market-based instruments for ecosystem services? A comparison of Costa Rica, Madagascar and France. Forest Policy and Economics, 37, 124-132. doi.org/ 10.1016/j.forpol.2013.09.001.

International Organization for Standardization (ISO). (n.d.). Costa Rica. Retrieved from www.iso.org/iso/about/iso_members/iso_member_body.htm?member_id=1667. 
Keohane, R. O. \& Oppenheimer, M. (2016). Paris: Beyond the climate dead end through pledge and review? Politics and Governance, 4(3), 142-151. doi.org/10.17645/pag.v4i3. 634.

Kim, E. \& Lyon, T. P. (2013). Beyond the dichotomy of symbolic versus substantive action. Academy of Management Proceedings, 2013(1). doi.org/10.5465/ambpp.2013. 14398abstract.

Kythreotis, A. (2015). Carbon pledges: Alliances and ambitions. Nature Climate Change, 5(9), 806-807. doi.org/10.1038/nclimate2764.

Matten, D. (2003). Symbolic politics in environmental regulation: Corporate strategic responses. Business Strategy and the Environment, 12, 215-226. doi.org/10.1002/bse.363.

Mol, A. P. J. \& Sonnenfeld, D. A. (2000). Ecological modernisation around the world: Perspectives and critical debates. New York, NY: Frank Cass Publishers.

Nandwani, S. S. (2006). Uses of solar energy in Costa Rica. Renewable Energy, 31, 689-701. doi.org/10.1016/j.renene.2005.08.008.

Newig, J. (2007). Symbolic environmental legislation and societal self-deception. Environmental Politics, 16(2), 276-296. doi.org/10.1080/09644010701211783.

Noppers, E. H., Keizer, K., Bolderdijk, J. W., \& Steg, L. (2014). The adoption of sustainable innovations: Driven by symbolic and environmental motives. Global Environmental Change, 25, 52-62. doi.org/10.1016/j.gloenvcha.2014.01.012.

Ostrom, E. (2010). Polycentric systems for coping with collective action and global environmental change. Global Environmental Change, 20(4), 550-557. doi.org/10.1016/ j.gloenvcha.2010.07.004.

Ovink, S. M., Ebert, K., \& Okamoto, D. (2016). Symbolic politics of the state: The case of in-state tuition bills for undocumented students. Socius: Sociological Research for a Dynamic World, 2, 1-15. doi.org/10.1177/2378023116647969.

Ponchner, D. \& Vargas, A. (2007, July 4). Gobierno lanzará iniciativa "Paz con la Naturaleza" [Government will launch initiative "Peace with Nature."] La Nacion. Retrieved from wvw.nacion.com/ln_ee/2007/julio/04/aldea1155221.html.

Replogle, J. (2015, December 4). Costa Rica's climate pledge: 5 things to know. The Tico Times. Retrieved from www.ticotimes.net/2015/12/04/costa-rica-climate-changepledge-5-things-know.

Republic of Costa Rica. (2009). Reglamento orgánico del Ministerio de Ambiente, Energía y Telecomunicaciones [Organic regulation of the Ministry of the Environment, Energy, and Telecommunications] (Executive Decree No. 35669-MINAET). Retrieved from www. digeca.go.cr/sites/default/files/decreto_ejecutivo_35669_reglamento_organico_del_ minaet_0.pdf.

Roberts, J. T., \& Parks, B. C. (2007). A climate of injustice: Global inequality, north-south politics, and climate policy. Cambridge, MA: MIT Press. 
Rogelj, J., Elzen, M. D., Hohne, N., Fransen, T., Fekete, H., Winkler, H., Schaeffer, R., Sha, F., Riahi, K., \& Meinshausen, M. (2016). Paris agreement climate proposals need a boost to keep warming well below $2^{\circ} \mathrm{C}$. Nature, 534, 631-639. doi.org/10.1038/nature18307.

Schutt, R. K. (2009). Investigating the social world: The process and practice of research. Thousand Oaks, CA: Pine Forge Press.

Sherwood, D. (2007, July 27). Peace with Nature plan draws fire. The Tico Times. Retrieved from www.ticotimes.net/2007/07/27/peace-with-nature-plan-draws-fire.

Speck, D. L. (2010). A hot topic? Climate change mitigation policies, politics, and the media in Australia. Human Ecology Review, 17(2), 125-134.

Vargas, A. (2007, August 2). Universidad Earth se declara neutra en carbono [Earth University declares itself carbon neutral]. La Nacion. Retrieved from www.nacion.com/ ciencia/universidad-earth-se-declara-neutra-en-carbono/7U62ZTY37BEW3FVMCNJ EWRLMUI/story/.

World Bank. (2019). DataBank. Retrieved from databank.worldbank.org/data/home.aspx.

Wysong, E., Aniskiewicz, R., \& Wright, D. (1994). Truth and DARE: Tracking drug education to graduation and as symbolic politics. Social Problems, 41(3): 448-472. doi.org/10.1525/sp.1994.41.3.03x0448f. 
This text is taken from Human Ecology Review, Volume 25, Number 1, 2019, published by ANU Press, The Australian National University, Canberra, Australia. doi.org/10.22459/HER.25.01.2019.02 